\title{
The Consequences of Supervisory Power - The Contingent Effect of Age and Length of Service
}

\author{
Kim Lian Lee (Corresponding author) \\ Faculty of Management \& Information Technology, University College Sedaya International \\ No. 1, Jalan Menara Gading, UCSI Heights, 56000 Kuala Lumpur, Malaysia. \\ E-mail: kllee@ucsi.edu.my \\ 1r. Dr. Low Guan Tui \\ Vesseltech Engineering Sdn Bhd \\ Jalan KPB4, Bukit Belimbing, Balakong, 43300 Seri Kembangan, Selangor, Malaysia \\ E-mail: drgtlow@gmail.com
}

\begin{abstract}
The superiors' power bases on work autonomy and satisfaction with supervision in Malaysian manufacturing companies was investigated. The influence of superiors and subordinates age and length of service were also explored. 210 data was collected from technical staff of manufacturing companies indicated that supervision of industrial people were most acceptable through the exercise of referent power, expert power and reward power. Among the power bases, reward power was most often exercised when the work autonomy is high. The work autonomy was found to be positively associated with the satisfaction with supervision. The perception of expertise was found to be associated more with superior and subordinate age differential rather than their length of service.
\end{abstract}

Keywords: Management, Organizational Behavior, Power Bases, Work Autonomy, Satisfaction, Managerial Supervision, Age, Length of Service

\section{Introduction}

This research seeks to find out the power impact on subordinates' work autonomy and satisfaction with supervision. There are two main sources of power in the organization (Bass, 1990). The first is related to one's position (positional power) to influence others who are lower in status. The other source is associated with the extent to which the wielder of power can grant affection, consideration, sympathy, recognition and secure relationships to others (personal power) which are normally acquired through personal attributes such as expertise, abilities, charisma or contacts he/she may have.

The importance of work autonomy as a variable for organizational study, on the other hand, has been well established as antecedents or outcomes of power. Spector's (1986) meta-analysis over 40 studies showed autonomy to be strongly associated with employee turnover, absenteeism, performance, motivation, physical ailments, emotional distress, and job dissatisfaction.

Furthermore, previous empirical research has devoted considerable attention on job design or job characteristics. Very litter research has been in finding a linkage of power applications and work autonomy. Knowing how power affects work autonomy and satisfaction will allow superiors to change or maintain their power bases to achieve desirable outcomes.

\subsection{Objectives of the Study}

The foundation of this study is based on the interaction among key variables as depicted in Figure 1 (Note 1). This study also analyzed the impact of age and length of service on power bases, work autonomy and satisfaction.

The applicability of this research is limited to only superior-subordinate dyadic relationships in Malaysian manufacturing companies. This industry is selected for the reason that it represents the fastest growing industry. It also typifies an industry of high economic activities where productivity, job innovation and effectiveness are of central concern. Knowledge gained in this area may be useful toward a more effectual industrial management.

\section{Literature Review}

\subsection{The Bases of Power}

Several classifications have been used in differentiating bases of social power in organizations (Peabody, 1961; Etzioni, 1964; Patchen, 1974; Twomey, 1978; Kipnis, Schmidt \& Wilkinson, 1980; Shukla, 1982; Rahim, 1989). 
Bases of power typology suggested by French and Raven (1959) are among the most popularly applied in research (Cobb, 1980; Frost \& Stahelski, 1988; Rahim, 1989; Rahim, Antonioni, Krumov, \& Illieva, 2000). French and Raven defined bases of power as below:

\subsubsection{Coercive Power}

Coercive power involves the concept of influence based upon "the expectation of punishment for failure to conform to an influence attempt". The strength of coercive power depends on the magnitude of the "negative valence of the threatened punishment multiplied by the perceived probability that a power recipient can avoid the punishment by conformity".

\subsubsection{Expert Power}

This power usually manifests in information, knowledge and wisdom, in good decision, in sound judgment and in accurate perception of reality. Expert power is restricted to particular areas as the "expert" tends to be specialised.

\subsubsection{Reward Power}

Reward power is derived from the ability to facilitate the attainment of desired outcomes by others. It is a form of social power is closely related to coercive power. If one conforms to gain acceptance, reward power is a work. However, if conformity takes place to forestall rejection, coercive power has to be exercised.

\subsubsection{Referent Power}

This involves the concept of "identification", which French and Raven (1959) define as "a feeling of oneness or a desire for such an identity". If referring to a group, then an individual seeks membership in such group or has a desire to remain in an association already established. This base of power usually has a tremendous impact on interpersonal relationships.

\subsubsection{Legitimate Power}

Legitimate power is induced by norms or values of a group that individuals accept by virtue of their socialisation in the group. Legitimacy is dependent upon relationships between social positions, not on the personal qualities of role incumbents.

\subsection{Work Autonomy}

The type of power used to exercise control will impact upon the type of involvement on the part of the controlled subordinates. One variable that is likely to be affected by the variation in the exercise of self-control of the subordinates is work autonomy. Breaugh (1985) defined three autonomy facets as follows:

\subsubsection{Work Method Autonomy}

The degree of discretion/choice individuals have regarding the procedures/methods they utilise in going about their work.

\subsubsection{Work Scheduling Autonomy}

The extent to which workers feel they can control the scheduling/sequencing/timing of their work activities.

\subsubsection{Work Criteria Autonomy}

The degree to which workers have the ability to modify or choose the criteria used for evaluating their performance.

It should be emphasized that the essence of these definitions lies on employee's perceptions as regardless of the amount of autonomy subordinate really has in their work, it is how much they perceive that they have which affects their reactions to the job. Langer (1983) has recently provided substantial evidence that autonomy is a basic human need which if unfulfilled can affect an individual's physical and psychological well being. Autonomy has received considerable attention in the context of job characteristics (Hackman \& Oldham, 1976; Sims, Szilagyi, \& Keller, 1976). Loher, Noe, Moeller, and Fitzgerald (1985) have meta-analyse the relationship between job characteristics and job satisfaction, and found autonomy to be highly related to job satisfaction than any of the other job characteristics. Based on the above mentioned findings, it is anticipated that in the present study, job autonomy as one consequence of the various types of power applications should co-vary with satisfaction with supervision.

\subsection{Satisfaction with Supervision}

Job satisfaction is a collection of feelings or affective responses of the organizational members which are associated with the job situation within the organization. Smith, Kendal and Hulin (1969), in their well documented measure, the Cornell JDI (Cornell Job Descriptive Index) described five areas of satisfaction: the work itself, the supervision, the co-workers, the pay, and the opportunities for promotion on the job. Since the present study is on the superior-subordinate relationships, the job-facet satisfaction is most relevant to satisfaction with supervision. 
Clearly, from human relations perspectives, supervisory satisfaction is related to the personality traits of the superior which as his/her temperament, openness, industriousness, pleasantness etc. The positive side of all of these traits can enhance satisfaction. Related to the personal resourcefulness, supervisory satisfaction is also dependent on the superior's distinguishing qualities and abilities such as intelligence and knowledge.

\subsection{Age and Length of service}

Age and length of service were evaluated to enhance understanding of the manner in which the physiological and psychological changing of aging influence human behaviour and perception. A stream of research in organizational behaviour literature (Gibson \& Klien, 1970; Hunt \& Saul, 1975; Schwab \& Heneman, 1977; Churchill, Fords, \& Walker, 1976; Busch, 1980) provided the basis for developing and testing hypotheses on the effects of aging and length of service as they relate to the bases of social power and work autonomy.

\section{Hypotheses to be tested}

The following hypotheses were formulated for the study.

H1a: Superiors' non-coercive bases of social power (expert, referent, reward and legitimate) are positively associated with the subordinates' satisfaction with supervision.

H1b: Superiors' coercive base of social power is negatively associated with the subordinates' satisfaction with supervision.

H2: Subordinates' work autonomy is significantly and positively related to the development of reward and referent bases of social power in the relationship with superiors.

H3: Work autonomy is significantly and positively related to the satisfaction with supervision.

H4a: The superiors' expert, reward and referent power bases are negatively related to the subordinates' age.

$\mathrm{H} 4 \mathrm{~b}$ : The superiors' expert, reward and referent power bases are negatively related to the subordinates' length of service.

\section{Research Methodology}

\subsection{Sampling Design}

The sample was chosen from the members list of the Federation of Malaysian Manufacturers. Data from subjects were secured through survey questionnaires. A cover letter explaining the purpose of the study and a self-addressed and stamped envelope accompanied each questionnaire. It was also requested in the cover letter that the questionnaires were to be distributed to the technical staff of the company.

\subsection{Research Instruments}

All data used in the study consist of responses to questionnaire items. Measures of relevant constructs were discussed here.

\subsubsection{Bases of Supervisory Power}

The five French-Raven bases of supervisory power were measured by using the Rahim Leader Power Inventory (RLPI) (Rahim, 1988). This multi-item instrument uses a 5-point Likert scale to measure perceptions of subordinates regarding their superiors' bases of power. The instrument comprises of 29 items. The order of items was randomized in the questionnaire to avoid response bias. Also some items were phrased positively and others negatively to overcome the problems of acquiescence, i.e., "yea" or "nay" saying tendencies. The scores for negatively phrased items were reversed before analysis. The indices of the five power bases were constructed by averaging the subject's responses to the selected items belonging to each power base. This resulted in the creation of five continuous subscales. There was substantial evidence of the criterion-related validity of the inventory when tested against the measure of compliance with superior directives and wishes (Rahim, 1988). The test-retest and internal consistency reliabilities of the subscales ranged from .77 to .91 and .70 to .86 respectively.

\subsubsection{Work Autonomy}

Work autonomy was conducted using the instrument designed by Breaugh $(1985,1989)$ and Breaugh and Becker (1987). The instrument which is capable of measuring three facets: method, scheduling, and criteria of work autonomy, comprises of 9 items. The items were responded to on a 5-point Likert scale continuum in which a higher value indicates greater work autonomy. In an effort to avoid responses bias and the problem of acquiescence, the order of items was randomised and some items were phrased positively while others negatively when constructing the questionnaire. The scores for the negatively phrased items were reversed before analysis. The scale had undergone extensive construct validation processes (Breaugh \& Becker, 1987; Breaugh, 1989). The 
internal consistency reliability coefficient (alphas) was reasonably high (greater than 0.78 for all studies). Good factorial clarity had been observed in all component items of the scale. The confirmatory factor analysis confirmed that the autonomy scale fits the sample data. The validity of the scale had also been tested by examining its relationship with other theoretically related work variables, i.e. participation in decision making, supervisory satisfaction, general job satisfaction and role ambiguity. Although the three autonomy facet scales were seen as providing more useful information (Breaugh, 1985, 1989), in our case, where the interest is in the general relationship among variables and not in the precise organizational diagnosis, a global measure of autonomy is all that is needed. The global index of work autonomy is thus evaluated from the mean of unweighted sum of 9-item scale measure.

\subsubsection{Satisfaction with Supervision}

The instrument used to measure satisfaction with supervision is the updated version of the original Job Descriptive Index (JDI; Smith at el., 1969) which was later revised by Roznowski (1989). The instrument is made up of 18 items. The 3 point responses were dichotomised so that a negative response ("yes" to a negative item or "no" to a positive item) was scored 0. A positive response was scored 1. "I don't know" response ("?") was scored 0 because past research have discovered that these responses were more typically from dissatisfied employees rather than satisfied employees (Park, 1983; Segall, 1983; Smith et al., 1969). The revised scale was shown (Roznowski, 1989) to be more internally consistent than the original scale with the alpha coefficient of .912. The unweighted sum of the individual item score was used as a measure of satisfaction with supervision.

\subsection{Data Analysis Techniques}

Reliability and factor analysis was used to check the consistency and dimensionality of the scale items. Multiple regression analysis is performed to check the criterion-related validity of the scale items. Pearson Intercorrelation was used to measure the associations among the social power bases, work autonomy and satisfaction with supervision. Partial correlation was performed to assess the relationship between age and job tenure with the social power bases.

\section{Research Results and Discussions}

\subsection{Sample Characteristics}

Data from 230 respondents were received and only 210 data were usable. By ethnic group, $72 \%$ of the respondents were Chinese, $18 \%$ were Malay, and $8 \%$ were Indian, while other races made up the rest.

Attempts to obtain more female respondent to test male-female differences were not successful due to the much smaller proportion of female taking supervisory roles in the factories. A mere $7 \%$ female respondent reflects the male domination in the industrial sector.

More than $60 \%$ of the respondents were from factories located in the state of Selangor where factories were largely concentrated in the Klang Valley. Other states like Perak, Penang, Kedah and Perlis account for only $20 \%$ of the total respondents. The remaining respondents were from factories scattered in the states of Johore, Negeri Sembilan, Malacca and Pahang.

In terms of age, the highest proportion of respondents fell into the 31-40 years age group. They accounted for 50\% of the total number of respondents. This was followed by the 20-30 years age group (34\%), while those above 41 years old accounted for the remaining.

Overall, the education level of the respondents was high. Nearly $61 \%$ of the respondents had education up to university in technical field while $15 \%$ received university education in non-technical field. Only $24 \%$ of the respondents had no tertiary education. The high educational level was reflected in the position or the type of occupation held by the majority of the respondents i.e. 5 Assistant General Managers, 54 Divisional Manager and Assistants, 74 Engineers and Assistants, 11 Chemists, 32 Supervisors, 12 Plant Operators and the rest comprised of System Analysts, Draughtsmen, Quality Control Inspectors etc.

The average salary of the respondents was higher than the population's average. The survey data showed that $29 \%$ of the respondents earned more than RM5000 per month, 12\% earned RM4001 to RM5000 per month, 16\% earned RM3001 to RM4000 per month, and 13\% earned RM2001 to RM3000 per month.

On average, the respondents had worked in the present company for 7 years. It was noted that $22 \%$ of the total respondents had worked for one year or less in the present company, 23\% had worked between 2 to 4 years, $21 \%$ had worked between 5 to 8 years, and $17 \%$ had worked between 8 and 12 years, while only $12 \%$ of the respondents had worked longer than 12 years in the present company.

In terms of the organizational size, the survey had selected sample which represents the medium to large sized Malaysian manufacturing companies. The average number of employees of the factory sample as 275 . It was 
found that $41 \%$ of the factories had 25 to 100 employees, $24 \%$ had 101 to 200 employees, $14 \%$ had 201 to 400 employees, $10 \%$ had 401 to 1000 employees and $11 \%$ had more than 1000 employees.

Classifying the factories according to the type of business revealed that a greater portion of the factories manufactured machinery $(29 \%)$, followed by food $(13 \%)$, chemical $(13 \%)$ and the rest manufactured non-metal, basic metal, textile, wood and paper.

The survey also revealed the information about the respondent's superiors. Almost all of the superiors reported in the survey were males with the exception of one female. A majority of them were holding medium to high management positions. Racial composition of the superiors was: $76 \%$ Chinese, $7 \%$ Malay, $7 \%$ Indian and $10 \%$ from other races. On average, the superiors had worked in the organization for 11 years - far longer than the subordinates' average. Only $9 \%$ had worked for less than a year, $16 \%$ had worked between 1 and 5 years, 34\% had worked between 6 and 10 years, 15\% had worked between 11 to 15 years, $15 \%$ had worked between 16 to 20 years and the remaining $11 \%$ had worked more than 20 years in the present company. Most of the superiors were holding high positions in the company with $36 \%$ of them in the first hierarchical level, $31 \%$ in the second level, and $24 \%$ in the third level, while only a fraction of them were in the lower management positions. Their educational level was also strikingly high, with $70 \%$ of them having had tertiary education in technical field and $12 \%$ having had tertiary education in non-technical field. Only $18 \%$ had up to either primary or secondary education. By designation, 40 of the superiors were the Directors of companies, 32 were the General Manager, 89 were the Divisional Managers and the rest consisted of Assistant Manager, Engineers, Supervisors etc.

\subsection{Validating the Scales}

The data on the 29 power items was factor-analyzed. The selection of a factor and an item was guided by the criteria: Eigenvalue $>1.0$ and Scree Plot and factor loading $>0.4$, respectively (Ford, MacCallum \& Tait, 1986). The results are presented in Table 1 (Note 2).

The mean, standard deviation and standardized Cronbach Alpha and the corrected item-total correlation for each subscale is provided in Table 2. (Note 3) The internal consistency reliability coefficients for all the scales were satisfactory (Nunnally, 1978). All the scales had coefficient Cronbach Alpha greater than .70. A corrected item-total correlation is a correlation between an item's score and subscale score computed from the remaining items in the set. The item-total correlations for the five scales ranged between .29 and .76 .

A multiple regression analysis was run to test the relationship between the five bases of leader power and the subordinates' satisfaction with supervision. The results are presented in Table 3 (Note 4). The results showed that the referent, expert, and reward power bases positively influenced satisfaction with supervision

\subsection{Testing of Hypotheses}

H1a \& H1b: Power Bases and Supervisory Satisfaction. The correlational results in Table 4 (Note 5) provided good support for H1a. The non-coercive bases of social power (expert, referent, reward and legitimate) showed positive relationships with satisfaction with supervision. Referent power ranked highest among other power exercises (coefficient .64). This was followed by expert power and reward power which both had coefficients of correlation of 0.47. The ranking of intercorrelation was somewhat similar to the study of Rahim and Buntzman (1989) conducted on respondents with post graduate working experiences. It was expected that referent and expert power represent a high level of internalisation or inner acceptance. In the exercise of referent power, internalisation derived from the identification of power recipient with the wielder of referent power - a personalised commitment to the group or its representative. As Raven (1974) found out, the exercise of referent power tends to encourage a more satisfied, cooperative and prolonged relationships between superiors and subordinates.

Expert power benefits from an umbrella of authority which may go beyond superiors' specialised skills. Among technical staff, expertise emerges as a very important cue for acceptance and recognition of the superiors' direction as reflected in the present result. It most likely gains their compliance and least likely to provoke their resistance (Podsakoff \& Schriesheim, 1985). Similarly, greater satisfaction with supervision among subordinates may lead to greater cooperation and heightened dependence.

Both referent and expert power were labelled by Yukl (1981) as "personal" form of power. The present results supported the general view that "personal" power has a positive effect on the leader-subordinate relationship. The high degree of intercorrelations among the referent, expert and reward power bases served to temper the previous discussions and tended to suggest that while referent power emerged as the dominant explanatory power base, its effective utilisation might be tied, to some extend, to the superiors' exercise of a combination of other power bases i.e. in this case, expert and reward power bases. 
Although earlier findings (Warren, 1968) acknowledged that reward power shows less inner acceptance, the present correlational results indicated a high level of satisfaction with supervision. This power derives from control over positive or rewarding outcomes for subordinates is expected to be an effective means of influence to increase productivity in the organisation. Schopler and Layton (1974) held that the use of reward power is likely to increase the attraction between the manager and subordinates while coercive power is likely to decrease it. Too much emphasis of this power base, however, should be guarded against, since the withdrawal of positive sanctions is apt to result in the subordinates' reversion to their previous behaviour. Further, the effect of the inducement, even if continued, is subject to diminishing utility.

The legitimate power showed relatively lower correlation with the satisfaction with supervision. In the exercise of legitimate power, subordinates' responses tended to be dependent on the normative acceptance of the position and prerogatives of the organization at large including its leadership. The present result concurred with the conclusion made by Yukl (1981) that "position" power such as legitimate and coercive are less effective means of influence attempt.

The result for coercive power was not exactly consistent with hypotheses H1b. The study indicated that the amount of coercive power perceived to be held by a superior was not associated with supervisory satisfaction when it was earlier hypothesized to have negative association. However, the result failed to reach statistical significance. Past researchers also had mixed results with regard to this correlation. For example, Rahim and Buntzman (1988) weak positive; Busch (1980), Hinkin and Schriesheim (1989) - negative. The coercive power which is derived from control over negative or punishing outcomes for other does not appear to be a suitable power base for dealing with subordinates. The traditionalists believed that punishment is ineffective and can lead to discontinuation of social interaction. The present results however, neither confirmed nor disproved the effectiveness of punitive treatments to get things done but it was obvious that this power exercise should not lead to subordinates' satisfaction. Moreover, people could not be coerced into a deep-seated acceptance of organizational requirements.

H2: Power Bases and Work Autonomy. The relationship as appeared in Table 4 (Note 5) between the perceptions of supervisory power bases and the perceived amount of work autonomy given was significantly distinct where in the relationship with all but coercive power had been significance. The relationship was strongest with reward power $(\mathrm{r}=.37)$ followed by referent $(\mathrm{r}=.21)$, legitimate $(\mathrm{r}=.19)$, and expert power $(\mathrm{r}=.16)$. As autonomy is related to the organizational control - the ability to control over work method, work scheduling and work criteria, a basic premise of the argument that follows is the association of interrelationship between power bases and control. Autonomy provides an opportunity for subordinates to exercise influence on decisions relating to their work. Hence, it enhances their relative ability to control in the organization. The present result pointed to the conclusion that superiors who were perceived to exercise coercive power would tend to exercise greater management control, possibly by application of autocratic techniques. The reason for this was not conclusive. Many plausible explanations were possible, but it was believed that superiors who exercised coercive power held to the traditional view that power has a fixed value, and a function of organizational structure and formal authority, unilateral and vertical in direction. Thus, subordinates' attempts to exercise greater influence may be seen as a threat to superiors' control and power. Furthermore, as the power gap between superiors and subordinates will even likely to increase as a direct consequence of punitive treatments, the subordinates tend to prefer to avoid participation. The above explanation is in similar vein as the conclusion made by Gardell (1977) about the relationship between work autonomy and industrial democracy.

The non-coercive power bases correlate better with the work autonomy. Strong relationship between reward power and work autonomy implied that those who exercised control over positive and rewarding outcome accorded greater work autonomy to the subordinates. Though the degree of commitment toward work by the exercise of reward power has been questioned (Warren, 1968; Gemmill \& Wilemon, 1972) the rewards at least provide incentives for the subordinates to perform beyond the line of duty. The substantive outcome is visible only when one produces work beyond the normal expectations and control of the superior, otherwise reward is not necessary. The calculative involvement of subordinates to the application of this power underscores the importance of work autonomy in eliciting employees' responses. This conclusion was drawn from the assumption that people generally prefer greater work autonomy than less and that work autonomy can provide opportunities for greater outcomes. It appeared from this study that individual freedom and autonomy was contingent upon the exercise of reward power. In retrospect, it was inconceivable that reward power was exercised with no allowance for work autonomy in the present context.

The referent power which stems from a feeling on the part of the subordinates identify with the superior indicates subordinates' agreement with superiors in personal characteristics, decision style, etc. If the desire for work autonomy and the actual work autonomy given is aligned, the perception of referent power is reinforced. The 
referent power base helps to build trust in a relationship (Busch, 1980). This trust is reciprocal and thus we would expect that those who exercise referent power will accord sufficient work autonomy to their subordinates.

The relationship between legitimate power and autonomy was significant although not strongly correlated $(\mathrm{r}=0.19)$. This power is more dependent on the authority relationship (position power) than the individually-based power style. This managerial style were regarded as "traditional" by many management theorists as the superior-subordinate relationship is perceived to follow rigid hierarchical line and employees tend to have little say in the conduct of their work.

It was interesting to note that even though the expert power was highly correlated with satisfaction with supervision, its correlation with work autonomy $(\mathrm{r}=0.16)$ was not as pronounced as one would expect. This finding plays down the importance of work autonomy in contributing to the satisfaction with supervision that lead one to think that work autonomy may not be as important as the perception of power style in ensuring employees' satisfaction. It is obvious that professional expertise is not strongly related to work autonomy. Intuitively, if the subordinate perceived that the superior has greater expertise than himself/herself, he/she will tend to down rate his/her own capability at least in comparison with the superior's. Such perception will suppress the motivation for anticipation in decision making, the reciprocal of this might also be true, i.e. if the superior perceive his/her subordinate to be incompetent and lacking in skills, little autonomy will be accorded to them. This finding is consistent with the work of Fiorelli (1988) and Bennett (1982).

Overall, the results agreed with hypothesis H2. However, the present result should be used with caution as the measurement of both construct was not based on the objective measurement but on individual perceptions. Individual differences such as desire for power equalization, inner motivation, etc might intervene in the relationship between power and work autonomy.

H3: Work Autonomy and Supervisory Satisfaction. The relationship between work autonomy and satisfaction with supervision was not as strong as one would expect $(\mathrm{r}=.23)$. This was probably due to the reason that work autonomy and satisfaction with supervision was not very much a related concept. The former measured job characteristic from the perspectives of internalized pattern of self determination while the latter measured one's feelings about the nature of supervision at work. Nonetheless, an important common element appeared to exist between them that explained their positive and statistically significant relationship. It was assumed that the common element would be the degree or quality of supervision. The right degree of perceived supervision is synonymous with the quality of supervision perceived. Conceptually, satisfaction with supervision may be considered, in special cases, as a consequence of work autonomy, but it is not the action of work autonomy itself. Work autonomy may result in satisfaction or frustration with supervision. Blake and Mouton (1964) suggested that subordinates should be given greater power in decision making if they are exceptionally skilled, the superiors should exercise power in decision making in times of crises or when subordinates lack skills and abilities. The work autonomy is valued to the extent that it is within the capability of the participant. Moreover, satisfaction with supervision has a more general meaning which includes factors other than quality and amount of supervision. It includes personal traits of the superior, his/her knowledge and specialized skills, habits and personal disposition. Thus it can be concluded that all other factors being equal, increased autonomy when accorded within the decision making capabilities of subordinates is accompanied by greater satisfaction with supervision.

H4: Power Bases, Work Autonomy, Supervisory Satisfaction and Age and Length of Service. Table 5 (Note 6) contains partial correlations between: (1) the superiors' bases of power, work autonomy and the subordinates' age controlling for length of service, and (2) the superiors' bases of power, work autonomy and the subordinates' length of service controlling for age. The partial correlations between expert, referent and reward power and subordinates' age controlling for length of service were in the hypothesized negative direction (H4a). The relationship was not significant for the referent power. The coercive power was positively correlated with the subordinates' age controlling for length of service as expected although not at a statistically significant level. The relationship between legitimate power and subordinates' age controlling for length of service was not at all significant. The correlations between all the power bases and work autonomy with subordinates' length of service controlling for age were very weak and insignificant statistically. Thus, the results provided no support for H4b.

The findings suggested that superiors may need to adjust the nature of power relationship when dealing with subordinates of different ages and times on the job. Between these two variables, age had a greater impact on the nature of the relationship. In general, the older the subordinate, the less responsive he/she is to the superior expert and reward power bases. The subordinates' perception of the superior's expertise diminishes with the subordinate's age. This may be explained from enriched experience and knowledge as one matures with age which, serve to reduce the expertise gap between the subordinate and superior. The fact that expert power bases was insignificantly correlated $(r=.06)$ with subordinate's length of service when controlling for age while age and 46 
length of service were strongly correlated $(r=.67)$ seems to imply that length of service is of little consequence to the nature of the superior expert power relationship with the subordinate.

The results seemed to contradict the finding of Busch (1980) where length of service was found to be significantly and negatively related to the perception of expert power base of the superior. Several reasons could attribute to the differences in the results. First, the relatively higher educational background of the present respondents tends to play down the perception of expertise of superiors since the perception of expertise is confined to the job related activity. This is particularly true in the case when the subordinate has the technical and the professional background whereas the superior does not. Secondly, as one moves upward in organizational hierarchy with time, the nature of the job changes towards administrative roles where less emphasis is placed on the technical expertise and performance. Furthermore, a subordinate's perception of his/her expertise would not appreciable change as he/she moves from one company to the other so long as the kind of expertise required at the new company does not differ a great deal from the previous company. In such a case, the expertise gap between the subordinate and the superior is not perceived to be great even when the subordinate is new on the job. This explanation as well as the high job mobility among technical staff (average 2 previous jobs) lends support to the results that the present job tenure has little relevance as far as the perception of expert power base of the superior is concerned.

It is possible that the results may differ in the case of a technical staff who is entirely new on the job since his/her lack of experience and skill increases the tendency to view the superior higher on the expert power scale. It is also important to note from the Pearson correlational results in Table 4 that age of the superior alone does not ensure the effectiveness of superior expert power exercise $(r=.07)$, but the age gap between the superior and subordinate helps to increase the effectiveness of this power application $(\mathrm{r}=.20)$.

Compared to younger subordinates, the older subordinates were less responsive to reward power influence styles. Though not identifiable in the present study, many logical explanations are possible: such as lower motivation as age increase, higher salaries, changes in the intrinsic needs of the older subordinates, etc. In comparison, younger subordinates are usually more dynamic, enthusiastic and excited about the job and the reward it would bring for increased effort than the older subordinates. Thus their reward power perceptions tend to be more positive.

Although the relationship between coercive power and age was not statistically significant, the direction of relationship implies that the older subordinate tends to be more sensitive to and dissentious with the coercive power influence. Additionally, the present study failed to find any relationship between age or tenure of office with work autonomy and job satisfaction.

\section{Conclusion}

In general, the results of this study in relation to the administration of industrial people were quite consistent with our hypotheses based upon other organizational studies involving qualified and professional people. The instruments used in the study were tested and found to be applicable to our work environment. The results provided some tentative, but hopefully useful guidance for industrial administrators.

Intercorrelations among the five power bases showed that French and Raven (1959) power bases are not mutually exclusive. Reward and referent power bases were the most closely related followed by expert and referent power bases. The results revealed that referent power, expert power and to some degree reward power and legitimate power are found to be in association with each form of power. On the other hand, coercive power was the least correlated with all other power bases and most often stands alone. Among all of the power bases, coercive power was most related to reward power. It indicates that reward and coercive power tend to be used interchangeably. Though not considered as a serious disadvantage, notable intercorrelations among the five power bases denote the difficulty of finding power typology which is both exhaustive and conceptually distinct.

In assessing the effectiveness of the various influence attempts, the results suggested that referent, expert and reward power should be emphasized to ensure subordinate acceptance. Coercive power should be minimised in any influence attempt except in situation that call for such approach (e.g. time of crisis, low performance etc). The position of legitimate power was the lowest among the non-coercive power bases in influencing subordinates' behaviour for the case of management of technical and professional staff. Comparative studies revealed an interesting difference in the rank ordering of bases of the superiors' influence attempts. While the present study and Rahim and Buntzman (1989) study ranked referent and expert power as the most favourable and legitimate power the lowest among the non-coercive power bases in eliciting subordinates' acceptance, results of a survey conducted on account executives, office managers and public administrators (Bachman, Smith \& Slesinger, 1966) considered legitimate power as the most prominent or second in place. The results suggested a notion that the effectiveness of power influence does relate to the situation and context of the work environment.

The amount of autonomy given by superior was dependent on his/her willingness to delegate decision making down 
to the subordinate. The manner in which, control over individual's conduct of work lives was found to influence the individual's perception of the source of control. Superior who was perceived to exercise coercive power tends to exercise greater management control - giving little opportunity for the subordinates to be personally responsible for a meaningful portion of their works. The reward power is often used in exchange for compliance by subordinates. The subordinate's performance beyond the line of duty is made possible under high autonomy situations. The referent power tends to build trust in the interpersonal relationship and thus naturally more autonomy will be given by the superior to the subordinates. The perception of referent power is reinforced when one's desire for work autonomy and the actual work autonomy given is aligned. Management style that firmly rests on the legitimacy of authority usually offers inadequate work autonomy as rigid hierarchical structure limits and inhibits the subordinates' freedom in the conduct of their work.

Even though autonomy is said to be highly favoured for job involvement and also aspiration toward increased work participation at both the personal and group level, the present study showed that work autonomy may not result in exceptionally greater satisfaction with supervision. It was concluded that the work autonomy will lead to greater satisfaction with supervision only if the subordinates feel that the degree of work autonomy is appropriate, within the capability of the subordinates and fits that psychological needs of the subordinates. Generally, the results of the study did support the idea that the employees' satisfaction with supervision is favoured by a design of jobs that allow for high autonomy and high demands on skills and cooperation.

The relationships between the superiors' bases of power and subordinates' age and length of service were generally weak. Nonetheless, the findings did suggest that superiors may need to adjust the nature of power relationship depending upon the subordinates' age. The perception and perhaps the effectiveness of reward and expert influence styles tended to diminish with the subordinate's age. Job tenure had little bearing on the perception of power bases. The study showed that the older superior tended to exercise least of reward power than the younger superior. It was also found that the nature of superior-subordinate expert relationship was more distinct when the age gap between them increases. As much as the result tended to suggest, the researchers did not presuppose that age per se was the crucial factor which explained the nature of this relationship. It was rather the constellation of variables which covary with age such as pay, levels of hierarchy in the organization, job tenure, life orientation, knowledge, maturity etc that are likely to cause the difference in the perception and effectiveness of power style.

\section{References}

Bachman, J.G., Smith, C.G. \& Slesinger, J.A. (1966). Control, performance, and satisfaction: An analysis of structural and individual effects. Journal of Personality and Social Psychology, 4, 127-136.

Bass, B.M. (1990). Handbook of Leadership: Theory Research and Managerial Applications. The Free Press, London.

Bennett, F.C. (1982). The pediatrician and the interdisciplinary process. Exceptional Children, 48, 306-314.

Blake, R.R. \& Mouton, J.S. (1964). The Managerial Grid._Houston, Texas: Gulf Publishing Co.

Breaugh, J.A. (1985). The measurement of work autonomy. Human Relations, 38, 551-570.

Breaugh, J.A. (1989). The work autonomy scales: additional validity evidence. Human Relations, 42, 1033-1056.

Breaugh, J.A. \& Becker, A.S. (1987). Further examination of the work autonomy scales: Three studies. Human Relations, 40, 381-400.

Busch, P. (1980). The sales managers' bases of social power and influence upon the sales force. Journal of Marketing, 44(4), 91-101.

Churchill, G.A., Ford, N.M., Jr., \& Walker, O.C., Jr. (1976). Organizational climate and job satisfaction in the sales force. Journal of Marketing Research, 13, 323-332

Cobb, A.T. (1980). The sales managers' bases of social power and influence upon the sales force. Journal of marketing, 44 (4), 91-101.

Etzioni, A. (1964). Modern Organizations, Englewood Cliffs, New Jersey: Prentice Hall, 58-64.

Fiorelli, J.S. (1988). Power in work groups: Team member's perspectives. Human Relations, 41(1), 1-12.

Ford, J.K., MacCallum \& Tait, M. (1986). The application of exploratory factor analysis in applied psychology: A critical review and analysis. Personnel Psychology, 39, 291-314.

French, J.R.P. \& Raven, N. (1959). The bases of social power. In D. Cartwright (Ed.), Studies in Social Power, Ann Arbor: University of Michigan Press, pp.150-167.

Frost, D.E. \& Stahelski, A.J. (1988). The systematic measurement of French and Raven's bases of social power in 48 
workgroups. Journal of Applied Social Psychology, 18, 375-389.

Gardell, B. (1977). Autonomy and participation at work. Human Relations, 30(6), 515-533.

Gemmil, G.R. \& Wilemon, D. (1972). The product manager as an influence agent. Journal of Marketing, 36(1), 26-30.

Gibson, J.L. \& Klien, S.M. (1970). Employee attitude as a function of age and length of service, a reconceptualisation. Academy of Management Journal, 13(12), 411-425.

Hackman, J.R. \& Oldham, G.R. (1976). Motivation through the design of work: test of a theory. Organizational Behavior and Human Performance, 16, 250-279.

Hinkin, T.R. \& Schriesheim, C.A. (1989). Development and application of new scales to measure the French and Raven (1959) bases of social power. Journal of Applied Psychology, 74(4), 561-567.

Hunt, J.W. \& Saul, P.N. (1975). The relationship of age, tenure and job satisfaction in males and females. Academy of Management Journal, 18(12), 690-702.

Kipnis, D., Schmidt, S.M. \& Wilkinson, I. (1980). Intraorganizational influence tactics: Explorations in getting one's way. Journal of Applied Psychology, 65, 440-452.

Langer, E.J. (1983). The Psychology of Control, Beverly Hills, California: Sage Publications.

Loher, B.T., Noe, R.A., Moeller, N.L. \& Fitzgerald, M.P. (19850. A meta-analysis of the relation of job characteristics to job satisfaction. Journal of Applied Psychology, 70, 280-289.

Nunnally, J.C. (1978). Psychometric Theory, New York: McGraw-Hill.

Park, R.K. (1983). Application of a graded response model to the assessment of job satisfaction. Unpublished doctoral dissertation, University of Illinois at Urbana-Champaign.

Patchen, M. (1974). The locus and basis of influence on organizational decisions. Organizational Behavior and Human Performance, 11, 195-221.

Peabody, R.L (1961). Perceptions of organizational authority: A comparative analysis. Administrative Science Quarterly, 6(4), 463-482.

Podsakoff, P.M., \& Schriesheim, C.A. (1985). Field studies of French and Raven's bases of power: Critique, reanalysis and suggestion for future research. Psychological Bulletin, 97, 387-411.

Rahim, M.A., (1988). The development of a leader power inventory. Multivariate Behavioral Research, 23, 491-502.

Rahim, M.A. (1989). Relationships of leader power to compliance and satisfaction with supervision, evidence from a national sample of managers. Journal of Management. 15, 545-557.

Rahim, M.A. \& Buntzman, G.F. (1989). Supervisory power bases, styles of handling conflict with subordinates, and subordinate compliance and satisfaction. Journal of Psychology, 123, 95-210.

Rahim, M.A., Antonioni, D., Krumov, K. \& Illieva, S. (2000). Power, conflict, and effectiveness: a cross-cultural study in the United States and Bulgaria. European Psychologist, 5 (10), 28-33.

Raven, B.H. (1974). The comparative analysis of power and influence. In J.T. Tedeschi (Ed.), Perspective on Social Power, Chicago: Aldine.

Roznowski, M. (1989). Examination of the measurement properties of the job descriptive index with experimental items. Journal of Applied Psychology, 74(5), 805-814.

Schopler, J. \& Layton, B. (1974). Attributions of interpersonal power. In J. Tedeschi, (Ed.), Perspectives on Social Power. Chicago: Aldine.

Schwab, D.P. \& Heneman, H.G. (1977). Age and satisfaction with dimensions of work. Journal of Vocational Behavior, 10(4), 212-220.

Segall, D.O. (1983). An answer to a question about the JDI. Unpublished Manuscript. University of Illinois at Urbana-Champaign.

Sims, H.P., Szilagyi, A. \& Keller, R.T. (1976). The measurement of job characteristics. Academy of Management Journal, 19, 196-213.

Smith, P.C., Kendall, L.M. \& Hulin, C.L. (1969). The Measurement of Satisfaction in Work and Retirement: A Strategy for the Study of Attitudes, Chicago: Rand McNally. 
Spector, P.E. (1986). Perceived control by employees: A meta-analysis of studies concerning autonomy and participation at work. Human Relations, 39, 1005-1016.

Twomey, D.F. (1978). The effects of power properties on conflict resolution. Academy of Management Review, 21, 144-150.

Warren, D.I. (1968). Power, visibility, and conformity in formal organizations. American Sociological Review, 33, 951-970.

Yukl, G.A. (1981). Leadership in Organizations. Englewood Cliffs, N.J.: Prentice Hall.

Notes

Note 1. Supervisory Power Bases, Work Autonomy and Satisfaction with Supervision

Note 2. Factor Structure Matrix for Varimax Rotated Factor Solution

Note 3. Reliability of Scales: Power Bases, Work Autonomy and Satisfaction with Supervision

Note 4. Multiple Regression Analysis: Power Bases and Satisfaction with Supervision

Note 5. Pearson Correlations among Key Variables

Note 6. Partial Correlations Controlling for Subordinates' Age and Time-On-Job

Bases of Supervisory Power

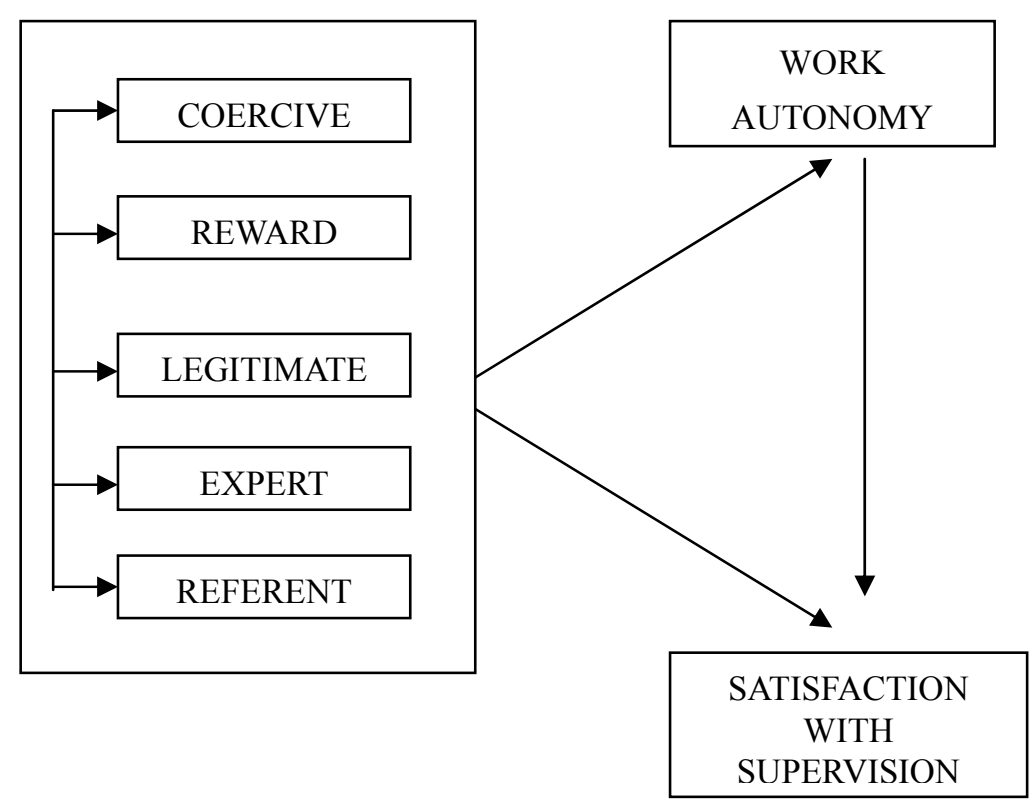

Figure 1. Supervisory Power Bases, Work Autonomy and

Satisfaction with Supervision 
Table 1. Factor Structure Matrix for Varimax Rotated Factor Solution

\begin{tabular}{|c|c|c|c|c|c|c|c|}
\hline \multirow[b]{2}{*}{ Item } & \multirow[b]{2}{*}{ Power Bases/Items } & \multicolumn{6}{|c|}{ Factors } \\
\hline & & EX & $\mathrm{RE}$ & $\mathrm{RF}$ & $\mathrm{CO}$ & LE & \\
\hline \multirow[t]{2}{*}{ No } & & $\mathrm{I}$ & II & III & IV & $\mathrm{V}$ & $\mathrm{h}$ \\
\hline & Expert Power (EX) & & & & & & \\
\hline 3. & $\begin{array}{l}\text { I approach my superior for advice on } \\
\text { work-related problems because he/she is } \\
\text { usually right. }\end{array}$ & .46 & .10 & .12 & -.08 & .15 & .28 \\
\hline 5. & $\begin{array}{l}\text { When a tough job comes up my superior has } \\
\text { the technical "know how" to get it done. }\end{array}$ & .73 & .09 & .14 & .00 & .08 & .57 \\
\hline 7. & $\begin{array}{l}\text { My superior has specialized training in } \\
\text { his/her field. }\end{array}$ & .65 & .26 & .13 & .13 & .11 & .54 \\
\hline 10. & $\begin{array}{l}\text { My superior does not have the expert } \\
\text { knowledge I need to perform my job. }\end{array}$ & .62 & .07 & .11 & .05 & .10 & .50 \\
\hline 17. & $\begin{array}{l}\text { I prefer to do what my superior suggests } \\
\text { because he/she has high professional } \\
\text { expertise. }\end{array}$ & .65 & .10 & .16 & -.01 & .14 & .56 \\
\hline \multirow[t]{2}{*}{18} & $\begin{array}{l}\text { My superior has considerable professional } \\
\text { experience to draw from in helping me to do } \\
\text { my work. }\end{array}$ & .78 & .19 & .19 & -.02 & .07 & .70 \\
\hline & $\underline{\text { Reward Power (RE) }}$ & & & & & & \\
\hline 4. & $\begin{array}{l}\text { My superior can recommend me for merit } \\
\text { recognition if my performance is especially } \\
\text { good. }\end{array}$ & .19 & .53 & .17 & .11 & .22 & .42 \\
\hline 11. & $\begin{array}{l}\text { My superior can provide opportunities for } \\
\text { my advancement if my work is outstanding. }\end{array}$ & .20 & .64 & .19 & .10 & .08 & .56 \\
\hline 15. & $\begin{array}{l}\text { My superior cannot get me a pay raise even } \\
\text { if I do my job well. }\end{array}$ & -.05 & .39 & .24 & .18 & .00 & .39 \\
\hline 22. & $\begin{array}{l}\text { If I put forth extra effort, my superior can } \\
\text { take it into consideration to determine my } \\
\text { pay raise }\end{array}$ & .24 & .68 & .20 & .13 & .06 & .60 \\
\hline 24. & $\begin{array}{l}\text { I want to develop a good interpersonal } \\
\text { relationship with my superior. }\end{array}$ & .16 & .20 & .16 & .18 & .17 & .20 \\
\hline 27. & $\begin{array}{l}\text { My superior can get me a bonus for earning } \\
\text { a good performance rating. }\end{array}$ & .07 & .74 & .23 & -.02 & .01 & .63 \\
\hline \multirow[t]{2}{*}{28.} & $\begin{array}{l}\text { My superior can recommended a promotion } \\
\text { for me if my performance is consistently } \\
\text { above average. }\end{array}$ & .18 &.$\underline{82}$ & .15 & .10 & .06 & .74 \\
\hline & III $\quad \underline{\text { Referent Power }}(\mathrm{RF})$ & & & & & & \\
\hline 1. & My superior has a pleasing personality. & .15 & .17 & .68 & .06 & -.06 & .54 \\
\hline 12. & $\begin{array}{l}\text { I don't want to identify myself with my } \\
\text { superior. }\end{array}$ & .12 & .19 & .67 & .04 & .16 & .54 \\
\hline
\end{tabular}


Table 1 (Continued)

\begin{tabular}{|c|c|c|c|c|c|c|c|}
\hline \multirow[b]{2}{*}{ Item } & \multirow[b]{2}{*}{ Power Bases/Items } & \multicolumn{6}{|c|}{ Factors } \\
\hline & & EX & $\mathrm{RE}$ & $\mathrm{RF}$ & $\mathrm{CO}$ & LE & \\
\hline No & & $\mathrm{I}$ & II & III & IV & $\mathrm{V}$ & $\mathrm{h}$ \\
\hline 19. & $\begin{array}{l}\text { I admire my superior because he/she treats } \\
\text { every person fairly. }\end{array}$ & .33 & .32 & .70 & .02 & .07 & .71 \\
\hline 21. & I like the personal qualities of my superior. & .24 & .20 & .66 & .11 & .05 & .56 \\
\hline 25. & $\begin{array}{l}\text { My superior is not the type of person I } \\
\text { enjoy working with. } \\
\text { VI. Coercive Power (CO) }\end{array}$ & .26 & .26 & .52 & .02 & .11 & .63 \\
\hline 2. & $\begin{array}{l}\text { My superior can take disciplinary action } \\
\text { against me for insubordination/ } \\
\text { disobedience. }\end{array}$ & .03 & .08 & .07 & .48 & .21 & .30 \\
\hline 9. & $\begin{array}{l}\text { My superior can fire me if my performance } \\
\text { is consistently below standards. }\end{array}$ & -.03 & .00 & .00 & .78 & .10 & .62 \\
\hline 14. & $\begin{array}{l}\text { My superior can suspend me if I am } \\
\text { habitually late in coming to work. }\end{array}$ & .05 & .13 & .07 & .44 & .08 & .34 \\
\hline 16. & $\begin{array}{l}\text { My superior can see to it that I get no pay } \\
\text { raise if my work is unsatisfactory. }\end{array}$ & -.08 & .17 & .00 & .65 & .00 & .47 \\
\hline 20. & $\begin{array}{l}\text { My superior can fire me if I neglect my } \\
\text { duties. }\end{array}$ & .06 & .00 & .09 & .77 & .00 & .60 \\
\hline & V. Legitimate Power (LE) & & & & & & \\
\hline 6. & $\begin{array}{l}\text { It is reasonable for my superior to decide } \\
\text { what he/she wants me to do. }\end{array}$ & .26 & .04 & .05 & .00 &.$\underline{.48}$ & .43 \\
\hline 8. & $\begin{array}{l}\text { My superior is justified in expecting } \\
\text { cooperation from me in work related } \\
\text { matters. }\end{array}$ & .04 & .11 & .18 & .20 & .54 & .42 \\
\hline 13. & $\begin{array}{l}\text { My superior's position entitles him/her to } \\
\text { expect support of his/her policies from me. }\end{array}$ & .12 & .10 & .14 & .12 & .68 & .57 \\
\hline 23. & $\begin{array}{l}\text { My superior's position does not give } \\
\text { him/her the authority to change the } \\
\text { procedures of my work. }\end{array}$ & .13 & .11 & -.13 & .12 & .45 & .35 \\
\hline 26. & $\begin{array}{l}\text { I should do what my superior wants } \\
\text { because he/she is my superior. }\end{array}$ & .16 & -.13 & -.05 & -.15 & .54 & .47 \\
\hline 29. & $\begin{array}{l}\text { My superior has the right to expect me to } \\
\text { carry out his/her instructions. }\end{array}$ & .07 & .10 & .04 & .09 & .60 & .39 \\
\hline & Eigenvalues & 6.7 & 2.4 & 2.0 & 1.2 & 1.2 & \\
\hline & Percentage of variance explained & 23.1 & 8.1 & 6.8 & 4.3 & 4.1 & \\
\hline
\end{tabular}


Table 2. Reliability of Scales: Power Bases, Work Autonomy and Satisfaction with Supervision

\begin{tabular}{lccccc}
\hline \multicolumn{1}{c}{ Scales } & $\begin{array}{c}\text { No. of } \\
\text { Items }\end{array}$ & M & SD & Item-Total Correlation & Cronbach Alpha \\
\hline Expert & 6 & 3.45 & .76 & .46 to .71 & .84 \\
Reward & 5 & 3.82 & .75 & .57 to .76 & .85 \\
$\quad$ Referent & 5 & 3.56 & .77 & .57 to .72 & .84 \\
$\quad$ Coercive & 5 & 3.71 & .71 & .40 to .60 & .76 \\
$\quad$ Legitimate & 6 & 3.88 & .53 & .37 to .54 & .73 \\
Work Autonomy & 9 & 3.82 & .58 & .42 to .74 & .85 \\
Satisfaction with & 18 & 13.10 & 4.30 & .29 to .64 & .86 \\
Supervision & & & & - & - \\
SDS & 10 & 6.26 & 2.00 & - & \\
\hline
\end{tabular}

Table 3. Multiple Regression Analysis: Power Bases and Satisfaction with Supervision

Dependent variable: Satisfaction with supervision

\begin{tabular}{lcccc}
\hline Predicted Variables & $\mathrm{b}$ & $\begin{array}{c}\text { Standard } \\
\text { Error }\end{array}$ & Beta & $\begin{array}{c}\mathrm{T} \\
\text { Value }\end{array}$ \\
\hline Legitimate & -.348 & .451 & -.043 & -.772 \\
Coercive & -.049 & .323 & -.008 & -.152 \\
Referent & 2.689 & .359 & .486 & $7.486 *$ \\
Expert & 1.055 & .350 & .188 & $3.020 * *$ \\
Reward & .818 & .364 & .142 & $2.248 * *$ \\
& & & & \\
\hline
\end{tabular}

$\mathrm{F}=34.749$

Significance $\mathrm{F}<0.0001$

$\mathrm{R}$ (adjusted) $=.447$

Intercept: $\mathrm{a}=-1.738$

* $\mathrm{p}<.0001$

$* * \mathrm{p}<.05$ 


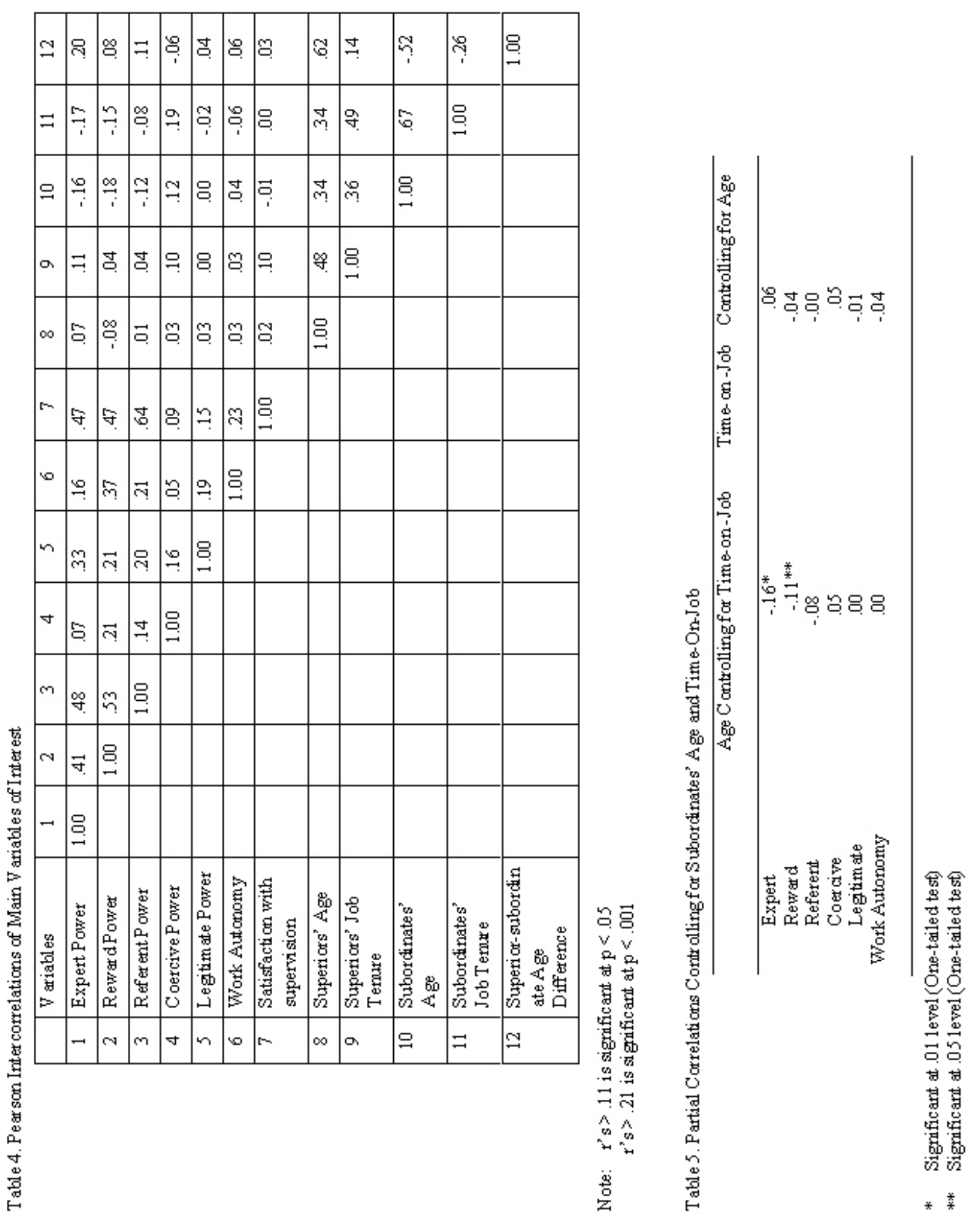

